Wolf, J., Stickland, L. H. \& Gondon, J. (1954). J. gen. Microbiol. 11, 17-26.

\title{
Enzymes concerned with Gas Formation by some Coliform Bacteria
}

\author{
By J. WOLF \\ Department of Agriculture
}

L. H. STICKLAND AND J. GORDON

School of Medicine, University of Leeds

SUMMARY: The absence of gas produced by certain coliform organisms during growth at elevated temperatures is not a result of an interference with the enzymes concerned, but rather an interference with the mechanism which brings about the appearance of these adaptive enzymes. A reconsideration of some of the evidence tends to support the view that formic hydrogenlyase is a separate entity, distinct from hydrogenase and formic dehydrogenase.

In the course of a study of coliform bacteria from soil, strains were encountered which had the property of fermenting glucose with production of acid and gas at $30^{\circ}$ (their optimum temperature for growth) and of producing acid but no gas at $37^{\circ}$. This behaviour is obviously similar to that of non-faecal strains of Escherichia coli, whose optimum temperature for acid and gas production is $37^{\circ}$, and which give acid but no gas from lactose at $44^{\circ}$, a fact of some importance in water analysis. Coliform organisms incapable of producing gas at higher temperatures have been described by several workers (e.g. Allen \& Harrison, 1936; Hiscox, 1934; Oxley, 1938) and have been referred to as pseudo-microaerogenic coliforms (Prescott, Winslow \& McCrady, 1946). No explanation of the phenomenon in enzymological terms has been given.

When these phenomena are observed for diagnostic purposes, the organisms are grown in a vessel containing sugar peptone water with a Durham tube, and the results are not quantitative. The more quantitative methods of assay of the factors concerned, described below, might make it possible to decide whether failure to produce gas at $37^{\circ}$ (soil origin) or $44^{\circ}$ (water origin) is due to the thermolability of the enzyme system concerned, or to failure of the organisms to elaborate these enzyme systems (or some part of them) at these higher temperatures.

\section{METHODS}

Organisms. Two strains of coliform organisms, B6 and C59, were used; their biochemical properties are given in Table 1. It is of some interest that at $44^{\circ}$ strain $\mathrm{C} 59$ not only produces no gas, but fails to utilize citrate when this is the sole source of carbon.

Preparation of cell suspensions. The organisms were grown in peptone broth to which glucose $(1 \%, \mathrm{w} / \mathrm{v})$ and $10 \mu$ mole $\mathrm{FeCl}_{3} / \mathrm{l}$. were added immediately before inoculation. Strain B6 was incubated at $30^{\circ}$, strain $\mathrm{C} 59$ at $37^{\circ}$ for $16 \mathrm{hr}$. The cultures (usually 1 l.) were cooled rapidly to $5-8^{\circ}$ in iced water and 
centrifuged at 2500 r.p.m. for $20 \mathrm{~min}$. The cells were washed twice with cool $0.01 \mathrm{M}$-phosphate buffer ( $\mathrm{pH} \mathrm{7 \cdot 0)}$ and finally resuspended in $25 \mathrm{ml}$. of the same phosphate solution. The dry weight of bacteria in the suspensions was of the order of $2 \mathrm{mg} . / \mathrm{ml}$., as measured by protein estimation by the method of Stickland (1951).

Table 1. Biochemical reactions of coliform organisms $\mathrm{B} 6$ and $\mathrm{C} 59$ at different growth temperatures

\begin{tabular}{|c|c|c|c|c|c|}
\hline \multirow[t]{3}{*}{ Organism: } & \multicolumn{2}{|c|}{$\mathbf{B} 6$} & \multicolumn{3}{|c|}{ C59 } \\
\hline & \multicolumn{5}{|c|}{ Growth temperature } \\
\hline & $30^{\circ}$ & $37^{\circ}$ & $30^{\circ}$ & $37^{\circ}$ & $44^{\circ}$ \\
\hline & \multicolumn{5}{|c|}{ Reactions } \\
\hline Indole & - & - & - & - & - \\
\hline Methyl red (MR) & + & + & - & + & + \\
\hline Acetoin & - & - & + & $(*)$ & - \\
\hline Citrate & - & - & + & + & - \\
\hline Glucose & $A$ and $G$ & $\mathbf{A}$ & $A$ and $G$ & $A$ and $G$ & $\mathbf{A}$ \\
\hline Gelatine & - & - & - & - & - \\
\hline
\end{tabular}

Methods of enzyme assay

Formic dehydrogenase. The usual Thunberg tube procedure was used, with $0.5 \mathrm{ml}$. phosphate buffer $(0.1 \mathrm{M}, \mathrm{pH} 7.0), 0.5 \mathrm{ml}$. methylene-blue solution $(0.002 \mathrm{M}), 0.5 \mathrm{ml}$. sodium formate $(0.1 \mathrm{M})$ and $0.5 \mathrm{ml}$. of suitably diluted bacterial suspension in each tube. The evacuated tubes were incubated in a water-bath at the appropriate temperature and the time to $90 \%$ reduction of the methylene blue noted. Blanks with the formate omitted were carried out on every occasion.

Hydrogenase. The test was similar to that for formic dehydrogenase, but the formate was omitted and the tube, after evacuation, filled with oxygen-free $\mathrm{H}_{2}$, re-evacuated, refilled, and finally left partially evacuated, with $c .60 \mathrm{~cm}$. $\mathbf{H g}$ pressure of $\mathbf{H}_{2}$. Before immersion in the water-bath the tubes were shaken to ensure solution of sufficient $\mathrm{H}_{2}$ in the solutions.

Formic hydrogenlyase. The usual Warburg manometric technique was used. The vessels contained $1 \mathrm{ml}$. phosphate buffer $(0 \cdot 1 \mathrm{M}, \mathrm{pH} \mathrm{7 \cdot 0}), 1 \mathrm{ml}$. sodium formate $(0 \cdot 25 \mathrm{M})$ and $1 \mathrm{ml}$. bacterial suspension. Vessels were evacuated 3 times and filled with oxygen-free nitrogen, and allowed to equilibrate $10 \mathrm{~min}$. before readings were started; $\mathrm{CO}_{2}$ was absorbed by $5 \% \mathrm{KOH}$ on filter-paper.

Glucose hydrogenlyase. This is a convenient name for the enzyme system which results in hydrogen production when glucose is the substrate. The measurements were made in exactly the same way as those for formic hydrogenlyase except that $1 \mathrm{ml}$. of $0 \cdot 25 \mathrm{M}$-glucose replaced the formate solution, and the phosphate buffer was at $\mathrm{pH} 6 \cdot 2$ instead of $7 \cdot 0$.

Units. The activity of enzyme is expressed as $\boldsymbol{Q}_{\mathrm{H}_{2}}=\mu \mathrm{l} . \mathrm{H}_{2}$ evolved $/ \mathrm{hr} . / \mathrm{mg}$. dry-wt. bacteria. $Q_{\mathrm{MB}}$ is a similar expression, in which 1 mole of methylene blue is taken as occupying $22 \cdot 4 \cdot 1$. 


\section{RESULTS}

To save repetition, $37^{\circ}$ is called the 'higher' temperature for strain $\mathbf{B} 6$ and $44^{\circ}$ the 'higher' temperature for strain $\mathrm{C} 59$. The corresponding normal temperatures are: $\mathrm{B} 6,30^{\circ} ; \mathrm{C} 59,37^{\circ}$.

Absence of formic hydrogenlyase and hydrogenase from suspensions grown at higher temperatures

Both strains grown at their higher temperatures showed complete absence of formic hydrogenlyase and of hydrogenase, and greatly decreased formic dehydrogenase activity compared with those of cultures grown at their normal temperatures (Table 2).

Table 2. Distribution of formic hydrogenlyase $(\boldsymbol{F H L})$, hydrogenase $(\boldsymbol{H})$ and formic dehydrogenase (FD), in suspensions grown at normal and at higher temperatures

Enzyme activity measured as $\boldsymbol{Q}_{\mathrm{H}_{\mathbf{Z}}}$ or $\boldsymbol{Q}_{\mathrm{MB}}$

\begin{tabular}{|c|c|c|c|c|c|c|}
\hline \multirow{5}{*}{$\begin{array}{l}\text { Organisms } \\
\qquad \text { B6 }\end{array}$} & \multicolumn{6}{|c|}{ Enzyme } \\
\hline & \multicolumn{3}{|c|}{$\begin{array}{l}\mathbf{Q}_{M B} \mathbf{Q}_{M B} \\
\text { Normal temperature }\left(\mathbf{Q}_{\mathrm{B}_{2}}\right)^{2}\end{array}$} & & $\begin{array}{l}\mathbf{Q}_{\mathrm{MB}} \mathbf{Q}_{\mathrm{MB}} \mathbf{Q}_{\mathrm{H}_{2}} \\
\text { Higher temperature }\left(37^{\circ}\right)^{2}\end{array}$ & $\begin{array}{c}\text { FHL } \\
\boldsymbol{Q}_{\mathrm{B}_{2}} \\
\mathbf{3 7 ^ { \circ } )}\end{array}$ \\
\hline & 60 & 16 & 80 & - & - & $\mathbf{0}$ \\
\hline & 29 & 13 & 77 & 8 & $\mathbf{0}$ & o \\
\hline & 17 & 14 & 93 & 13 & $\mathbf{0}$ & $\mathbf{0}$ \\
\hline \multirow{4}{*}{ C59 } & \multicolumn{3}{|c|}{ Normal temperature $\left(37^{\circ}\right)$} & \multicolumn{3}{|c|}{ Higher temperature $\left(44^{\circ}\right)$} \\
\hline & 88 & 193 & 350 & 11 & 0 & 0 \\
\hline & 63 & 47 & 450 & 5 & o & o \\
\hline & 77 & 61 & 149 & - & - & $\mathbf{0}$ \\
\hline
\end{tabular}

Stability at the higher temperature of hydrogenlyase in strains B6 and C59 grown at the normal temperature

When $\mathrm{B} 6$ was grown in glucose broth at $30^{\circ}$ or $\mathrm{C} 59$ in the same medium at $37^{\circ}$ the washed suspensions showed, at the normal temperature for each strain, typical glucose hydrogenlyase and formic hydrogenlyase activity with $\boldsymbol{Q}_{\mathbf{B}_{\mathbf{2}}}$ values in the range 100-400. When these manometric tests were carried out at the higher temperature for the given strain, the activity was initially as great as, or greater than, that at the normal temperature. In some experiments, however, the rate of $\mathbf{H}_{2}$ evolution at the higher temperature began to diminish rapidly after about $1 \mathrm{hr}$. This might indicate a greater instability of the enzymes at the higher than at the normal temperature, and thus might account for the absence of the enzymes in the bacteria grown at the higher temperature. However, it was soon found that the cessation of $\mathbf{H}_{2}$ evolution was to be attributed not specifically to the higher temperature, but to the low $\mathrm{pH}$ value caused by glucose breakdown. This change of $\mathrm{pH}$ could not be prevented by increased buffering, as this in itself inhibited the enzymes concerned; thus increasing the phosphate concentrations from 0.03 to $0.3 \mathrm{M}$ was sufficient to cause complete inhibition of gas production. 
That the cessation of gas production was due to decrease of $\mathrm{pH}$ was proved by two procedures: $(a)$ the addition of alkali from the side-arm of the vessel at the moment when the rate of gas production had reached a negligible figure; (b) a comparison of the duration of the linear production of hydrogen with different concentrations of bacteria.

(a) In experiments at $37^{\circ}$ the evolution of $\mathbf{H}_{2}$ from glucose usually ceased abruptly after $30-60 \mathrm{~min}$., the $\mathrm{pH}$ value of the reaction mixture then being $c .5$.

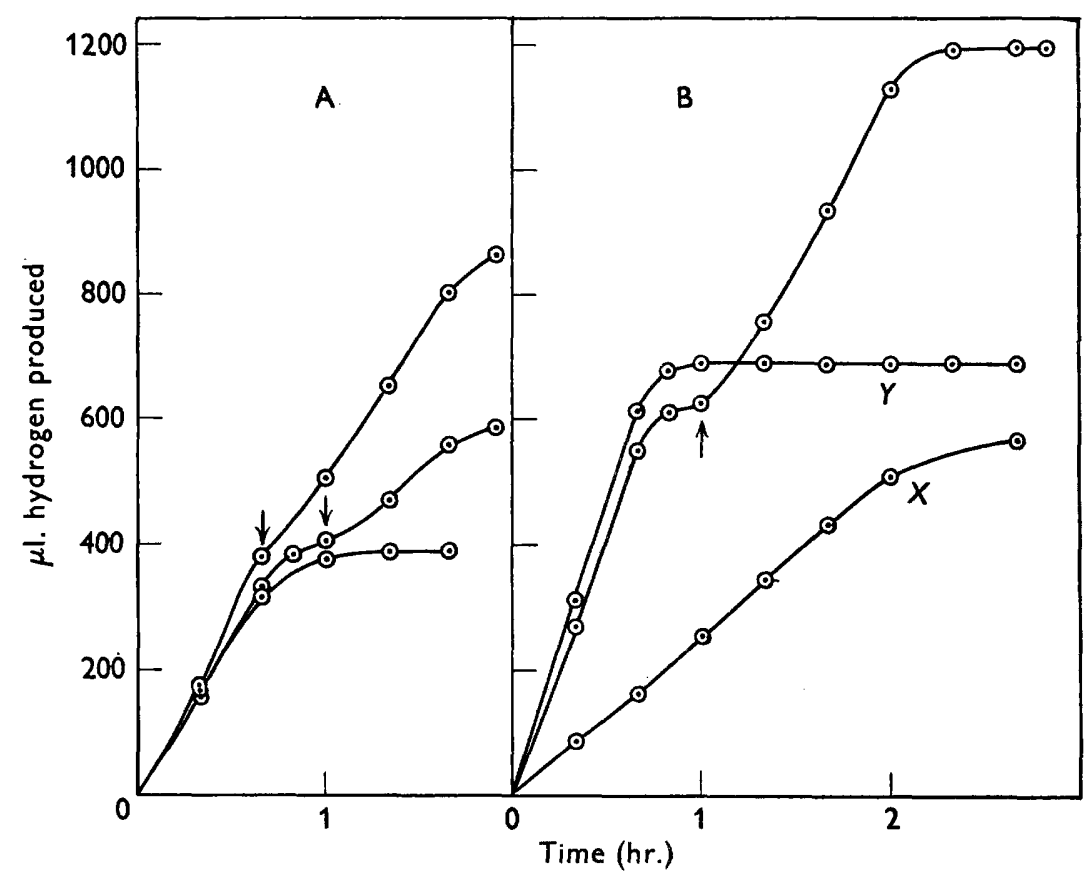

Fig. 1. The maintenance, or restoration, of hydrogen production from glucose by a suspension of washed bacteria of strain B 6, brought about by addition of alkali. At the points marked by an arrow, $0.2 \mathrm{ml} .0 .4 \mathrm{~N}-\mathrm{NaOH}$ was added to the Warburg vessel from the side-arm. Curve $X(B)$ shows the course of hydrogen production by a quantity of bacteria one-half of that used to produce curve $Y$.

When, just before this point was reached or immediately after, enough $\mathrm{NaOH}$ (usually $0.2 \mathrm{ml} .0 .4 \mathrm{~N}$ ) was tipped in from the side-arm of the Warburg vessel to restore the $\mathrm{pH}$ to $7 \cdot 0, \mathrm{H}_{2}$ production was immediately resumed at a rate approaching that observed initially. When the adjustment of the $\mathrm{pH}$ value was delayed, the recovery was progressively less complete, showing that the inactivation by acidity rapidly became irreversible (Fig. $1 \mathrm{~A}$ and $\mathrm{B}$ ).

(b) With a more dilute bacterial suspension the acidification of the medium was slower; under these conditions the reaction was more prolonged, and sometimes continued linearly for several hours before it was stopped by the change of $\mathrm{pH}$ (Fig. $1 \mathrm{~B}$ curves $\mathrm{x}$ and $\mathrm{y}$ ).

The attempt to determine the stability of glucose hydrogenlyase at the 
higher temperature was clearly frustrated by the effect of the accompanying $\mathrm{pH}$ change, so it was thought worthwhile to determine the stability of this enzyme in the absence of glucose, although in general enzymes are less stable to adverse conditions in absence of substrate. Suspensions of strains B6 and C59 in dilute buffer, having been grown in glucose broth at the normal temperature (for enzyme production), were held at the higher temperature for various periods of time, and then tested manometrically for their glucose hydrogenlyase content (Fig. 2). The results indicated different degrees of stability of the enzyme in the two strains. The enzyme was relatively stable for $2 \mathrm{hr}$. but was completely inactive after $c .4 \mathrm{hr}$. at the higher temperature. Two curious points noted in these experiments were: (i) in cases where the enzyme had been partially heat-inactivated, it showed a very rapid and quantitative recovery when incubated in glucose at the lower temperature; (ii) hydrogenase, far from being destroyed at the same time as the hydrogenlyase, showed an increase in apparent activity, sometimes as much as fivefold. These two observations were further investigated.

\section{Recovery of glucose hydrogenlyase activity in suspensions in which this enzyme had been lost through heating}

Suspensions grown at the normal temperature in glucose broth and not heated at the higher temperature, when tested for glucose hydrogenlyase at $\mathrm{pH} 7$ showed an initially linear $\mathbf{H}_{2}$ production, which/then gradually accelerated by some $30 \%$ as the $\mathrm{pH}$ value dropped to the optimum (pH 6.2). Similar suspensions heated at the higher temperature for $c .2 \mathrm{hr}$. showed a similar linear gas production; after $4 \mathrm{hr}$. heating they showed a decrease of $c .66 \%$ in initial velocity, with a rapid recovery during the first $30 \mathrm{~min}$. to a speed equal to that of the unheated control. After $6-8 \mathrm{hr}$. of heating the loss of activity was usually $90-100 \%$; the recovery then showed a lag of about $1 \mathrm{hr}$., and was not complete until $2 \mathrm{hr}$. from the beginning of the experiment. With longer heating the lag was longer, but the velocity ultimately attained was of the same order. These points are illustrated in Fig. 3. When formate was used as substrate instead of glucose, the disappearance of the enzyme took place at a similar rate, but no recovery was ever observed.

Further experiments were directed to determine whether this recovery of enzyme activity was associated with growth. For this purpose viable counts and total cell protein determinations were carried out on suspensions before and after the experiment. The viable count always showed a decrease and the total cell protein determination no change during the recovery period (Table 3). The absence of change in total bacterial protein precludes satisfactorily any increase in the total mass of bacteria present, but does not exclude the possibility that a few cell divisions had occurred. This could best have been tested by carrying out total cell counts, but this was rendered difficult and inaccurate by the clumping of cells which took place at the rather acid $\mathrm{pH}$ values reached in these experiments. The same reason might account for the apparent decrease in viable count, which was not expected. 


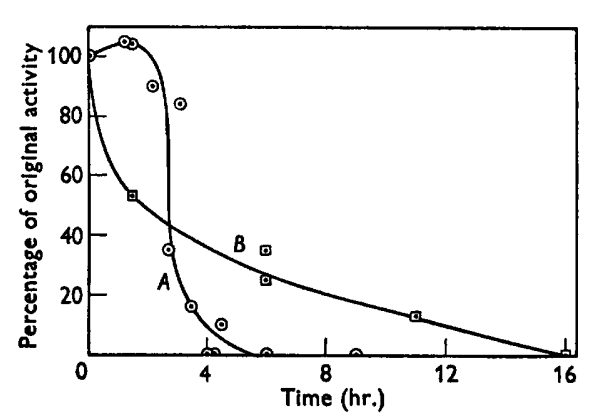

Fig. 2

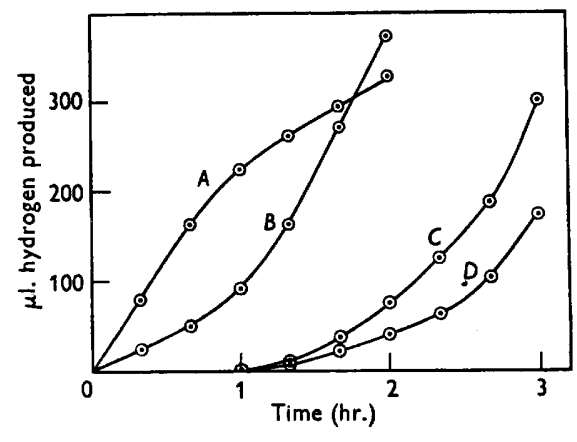

Fig. 3

Fig. 2. The rate of loss of glucose hydrogenlyase activity of suspensions of bacteria heated at $7^{\circ}$ above the normal growth temperature. Curve $A$, strain C59 heated at $44^{\circ}$; curve $B$, strain $\mathrm{B} 6$ heated at $37^{\circ}$.

Fig. 3. The recovery of glucose hydrogenlyase activity in bacterial suspensions in which this activity had been destroyed by heating. Strain C59. Curve $A$, unheated suspension; curve $B$, suspension heated $3 \frac{1}{2} \mathrm{hr}$. at $44^{\circ}$; curve $C$, suspension heated $6 \mathrm{hr}$. at $44^{\circ}$; curve $D$, suspension heated $9 \mathrm{hr}$. at $44^{\circ}$.

Table 3. Viable count and total protein content of heated and unheated suspensions of organisms B 6 before and after the recovery of the glucose hydrogenlyase at $30^{\circ}$

Before heating $6 \mathrm{hr}$. at $37^{\circ}$ (A)

After heating $6 \mathrm{hr}$. at $37^{\circ}$ (B)

Experiment 1

$\overbrace{\begin{array}{c}\text { Viable } \\ \text { count } \\ (\text { cells } / \mathrm{ml} .)\end{array}}^{\begin{array}{c}\text { Protein } \\ \text { content } \\ (\mathrm{mg} . / 3 \mathrm{ml} .)\end{array}}$

$25 \times 10^{9}$

$25 \times 10^{9}$

$20 \times 10^{9}$

$20 \times 10^{9}$
Experiment 2

$\begin{array}{cc}\begin{array}{c}\text { Viable } \\ \text { count } \\ \text { (cells } / \mathrm{ml} .)\end{array} & \begin{array}{c}\text { Protein } \\ \text { content } \\ (\mathrm{mg} . / 3 \mathrm{ml} .)\end{array} \\ \begin{array}{c}17 \times 10^{9} \\ 13 \times 10^{9}\end{array} & \mathbf{1 . 7 5} \\ \mathbf{6} \times 10^{9} & 1.70 \\ 8 \times 10^{\circ} & 1.77 \\ & 1.66\end{array}$

\section{Increase in hydrogenase activity during heating}

In suspensions of organism $\mathbf{C 5 9}$ or B 6, grown in glucose broth at the normal temperature, the activities of formic dehydrogenase and of hydrogenase were roughly equal. When either organism suspended in dilute phosphate buffer at pH 7.0 was heated to $7^{\circ}$ above its normal temperature, the formic dehydrogenase activity either remained constant or sometimes showed a very small increase. The hydrogenase activity, on the other hand, simultaneously with the complete disappearance of formic hydrogenlyase, showed a remarkable increase, amounting usually to $300 \%$ after $6 \mathrm{hr}$. of heating. This increased activity persisted after more prolonged heating, even up to $16 \mathrm{hr}$. (Fig. 4).

\section{Affinity of formic dehydrogenase and formic hydrogenlyase}

Much evidence has now been accumulated (Umbreit, 1951) which tends to indicate that formic hydrogenlyase is not an individual enzyme, but rather represents a linking of formic dehydrogenase and hydrogenase through a postulated and so far unidentified hydrogen carrier. In our experiments the 


\section{Gas formation by coliform organisms}

simultaneous absence of hydrogenlyase and hydrogenase from suspensions grown at a temperature above the normal, points in the same direction. The disappearance of hydrogenlyase concurrently with a fivefold increase in hydrogenase does not fit so well, but could be explained as an effect of the higher temperature on the hydrogen-transporting coenzyme, although it would be unusual to find a coenzyme more heat-labile than the enzymes it linked together.

Evidence concerning this may be obtained from a consideration of the relationship between formate concentration and the rates of the two processes, viz. transfer of hydrogen from formate to carrier (formic dehydrogenase, using methylene blue in place of the intracellular carrier) and evolution of molecular hydrogen (formic hydrogenlyase). If in each process formic dehydrogenase were the enzyme concerned in the first attack on the formate, then this

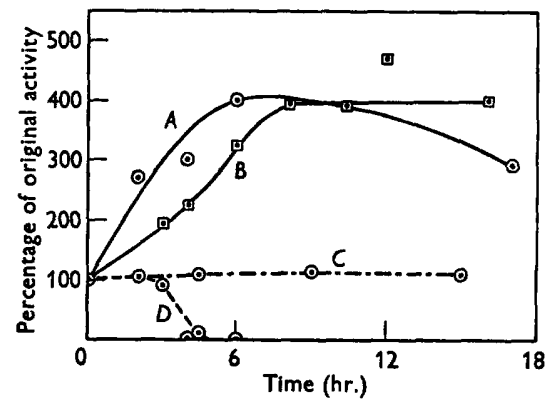

Fig. 4.

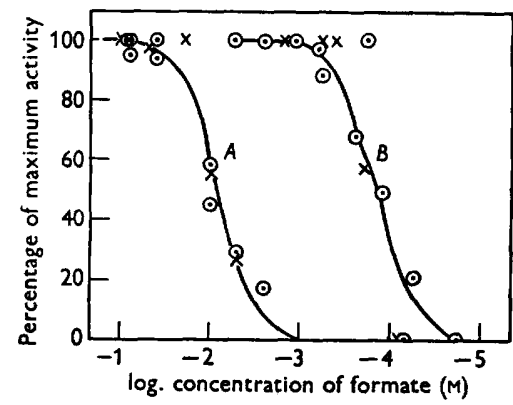

Fig. 5

Fig. 4. Increase in hydrogenase activity of suspensions of bacteria heated at $7^{\circ}$ above normal temperature. Curve $A$, strain $\mathrm{B} 6$ heated at $37^{\circ}$; curve $B$, strain $\mathrm{C} 59$ heated at $44^{\circ}$. For comparison are included the effects of similar heating on formic dehydrogenase (curve $C$ ) and hydrogenlyase (curve $D$ ), both for strain $\mathbf{B 6}$.

Fig. 5. Comparison of the affinities of formic dehydrogenase and formic hydrogenlyase. Curve $\boldsymbol{A}$, hydrogenlyase; curve $B$, dehydrogenase; $\odot$, strain $\mathrm{B} 6,30^{\circ}$; $\times$, strain $\mathrm{C59}, \mathbf{3 7}^{\circ}$.

relationship would be expected to be the same for the two processes. The relationship can be expressed numerically as the concentration of substrate at which half the maximum velocity of reaction is reached (Michaelis constant; $\boldsymbol{K}_{m}$ ); the reciprocal of this constant is a measure of the affinity of the enzyme for its substrate.

The affinities of formic dehydrogenase and formic hydrogenlyase were determined in Escherichia coli by Stephenson \& Stickland (1931) and found to be far from equal. These values have now been redetermined for strains B6 and C59, and the 100-fold difference in affinity between the two enzymes confirmed (Fig. 5).

\section{DISCUSSION}

The original purpose of this study, namely to find why certain strains of bacteria fail to produce gas when they are grown at a temperature $7^{\circ}$ higher than their normal growth temperature, has not been very far advanced. All that can be said is that the enzymes responsible for production of $\mathrm{H}_{2}$ from 
glucose are fairly stable at the 'higher' temperatures of the organisms used here, and the failure to produce gas must be attributed to a failure of those mechanisms which produce the adaptive hydrogenlyase system. Bacteria which have no hydrogenlyase activity have no hydrogenase activity either; how far these two phenomena may be related will be further discussed below.

The history of the theories on the nature of formic hydrogenlyase has been recently reviewed by Umbreit (1951). That more than one hydrogenlyase exists has been confirmed by Koepsell \& Johnson (1942), who demonstrated that formic acid was not an intermediate in the liberation of $\mathrm{H}_{2}$ from pyruvic acid by preparations from Clostridium butylicum. Present opinion is, in the main, in favour of a duplex theory, namely that hydrogenase and formic dehydrogenase are linked by a hydrogen-transporting coenzyme to constitute 'formic hydrogenlyase' which has no existence as a separate entity. Several new arguments can be offered which tend to weaken this theory.

(a) Such a hydrogen-transporting coenzyme would have to have an oxidation-reduction potential in the neighbourhood of that of the hydrogen electrode; it seems unlikely that any haematin derivative or other iron-containing coenzyme would have such a potential. The evidence derived from the effects of Fe-deficient media (Waring \& Werkman, 1944) seems therefore to be irrelevant.

(b) In many circumstances in which Escherichia coli is deficient in formic hydrogenlyase it is also deficient in hydrogenase. In our experiments this is confirmed for bacteria grown at the higher temperatures. However, there are two important exceptions : (i) in bacteria grown aerobically at normal temperature, i.e. unadapted; here it must be assumed that, as hydrogenase and formic dehydrogenase are both present in normal amounts, the postulated coenzyme is missing; (ii) in our experiments in bacteria grown at normal temperatures in glucose so as to contain formic hydrogenlyase, and then heated at the higher temperature until the hydrogenlyase activity has been destroyed. In such preparations formic dehydrogenase is quite stable and hydrogenase is actually increased in activity; therefore it must be assumed, on the duplex theory, that the postulated hydrogen carrier has been destroyed. We should have then the curious case of a coenzyme which was more heat-labile than the enzymes it linked.

(c) The affinity of formic dehydrogenase for its substrate is very high $\left(\boldsymbol{K}_{m}\right.$ is of the order of $10^{-4} \mathrm{M}$ ). If in each case the first action were between formic dehydrogenase and its substrate, the affinities should be the same and the subsequent fate of the hydrogen should not affect it. In fact, the affinity of formic hydrogenlyase is much less; $K_{m}=10^{-2} \mathrm{M}$. Lichstein \& Boyd (1953) produced evidence indicating that under certain conditions Aerobacter aerogenes can show formic hydrogenlyase activity while it contains no hydrogenase. This they took as proof of the separate existence of a formic hydrogenlyase; but the evidence is not entirely convincing as the enzyme tests, in the case of formic hydrogenlyase, involved incubation of the organisms with hydrolysed yeast extract and formate which were absent from the test for hydrogenase. It is not impossible that in the suspension incubated for $30 \mathrm{~min}$. with 
formate and hydrolysed yeast extract, hydrogenase, too, might have been regenerated.

The nature of the recovery of the power to produce hydrogen from glucose, by bacteria which had lost this power through incubation at the higher temperature, deserves some comment. These bacteria resemble unadapted bacteria in their complete lack of hydrogenlyase. Unadapted bacteria, however, cannot acquire the power of hydrogen production except by incubation with glucose (or formate) + an amino acid mixture (Stephenson \& Stickland, 1932; Pinsky \& Stokes, 1952). Pinsky \& Stokes suggested that the process of adaptation involves synthesis of enzyme protein from the amino acids supplied (or, if the duplex theory of hydrogenlyase be accepted, synthesis of the protein portion of the hydrogen-transporting carrier; cf. Yudkin, 1938; Mandelstam, 1952). Bacteria rendered devoid of hydrogenlyase through heating, on the other hand, show rapid recovery of enzyme when incubated with glucose alone (though not with formate alone). Their deficiency is therefore clearly not of the same nature as the deficiency in unadapted bacteria. The possibility that sufficient amino acids were liberated into the suspension during heating to allow readaptation to take place when the temperature was restored to normal was excluded by experiments in which the heated suspension was thoroughly washed before the recovery experiment; the recovery was only very slightly delayed by this treatment.

The change undergone by the hydrogenlyase system when inactivated by heating at $7^{\circ}$ above the normal temperature is less thorough-going, not involving destruction of protein, and is reversible at the normal temperature in the presence of glucose (but not formate). The kind of change that can be imagined is the splitting of a prosthetic group from a protein, or the oxidation or dephosphorylation of a prosthetic group to an inactive form. Glucose might reverse these changes by providing energy, or by providing strongly reducing conditions; the failure of formate to reverse the changes suggests that glucose acts by providing energy.

One of us (J.G.) is indebted to the Medical Research Council for a grant for expenses in aid of this work.

\section{REFERENCES}

Allen, L. A. \& Harrison, J. (1936). Characters of some coliform bacteria isolated from grass and grass silage. Ann. appl. Biol. $23,538$.

Hiscox, E. R. (1934). A coliform organism isolated from milk. J. Dairy Res. 5, 233.

Koepsell, H. J. \& Johnson, M. J. (1942). Dissimulation of pyruvic acid by cell-free preparations of Cl. butyricum. J. biol. Chem. 145, 379.

Lichstein, H. C. \& Boyd, R. B. (1953). The formic hydrogenlyase system of Aerobacter aerogenes. J. Bact. 65, 617.

Mandelstam, J. (1952). Studies in biochemical adaptation. The 'mass action' theory of enzyme adaptation. Biochem. J. 51, 674.

OxuEY, C. D. (1938). Observations on the occurrence of milk samples yielding a positive reaction for acid and gas in bile salt broth. Proc. Soc. Agric. Bact. (Abstract), p. 15.

Pinsky, M. J. \& Stokes, J. L. (1952). Requirements for formic hydrogenlyase adaptation in nonproliferating suspensions of Escherichia coli. J. Bact. 64, 151. 
Prescott, S. C., Winslow, C. E. A. \& McCrady, M. H. (1946). Water Bacteriology, 6th ed. p. 202. New York: John Wiley and Sons.

Stephenson, M. \& Stickland, L. H. (1931). Hydrogenase: a bacterial enzyme activating molecular hydrogen. Biochem. J. 25, 205.

Stephenson, M. \& Stickuand, L. H. (1932). Bacterial enzymes liberating molecular hydrogen. Biochem. J. 26, 712 .

Stickland, L. H. (1951). The determination of small quantities of bacteria by means of the biuret reaction. J. gen. Microbiol. 5, 698.

Umbreit, W. W. (1951). In Sumner \& Myrbäck, The Enzymes, 2, 329. New York: Academic Press.

Waring, W. S. \& Werkman, C. H. (1944). Iron deficiency in bacterial metabolism. Arch. Biochem. 4, 75.

Yudkin, J. (1938). Enzyme variation in micro-organisms. Biol. Rev. 13, 93.

(Received 5 December 1953)

Note. While this paper was in the press, results by Gest and his collaborators have appeared (Gest 1954) which offer further, but still inconclusive evidence for the duplex nature of formic hydrogenlyase.

\section{REFERENCE}

Gest, H. (1954). Oxidation and evolution of molecular hydrogen by microorganisms. Bact. Rev. 18, 43. 